Ya. Ya. Lebediev ${ }^{1}$, Cand. Sc. (Tech.), Assoc. Prof., orcid.org/0000-0002-2992-2581,

O. V.Stolbchenko ${ }^{1}$, Cand. Sc. (Tech.), Assoc. Prof., orcid.org/0000-0003-2003-4382,

A. A. Yurchenko ${ }^{1}$, Cand. Sc. (Tech.), Assoc. Prof., orcid.org/0000-0002-6074-0145,

I. O. Luts ${ }^{1}$, Cand. Sc. (Tech.), Assoc. Prof., orcid.org/0000-0003-0333-5730,

V.V. Kovbasa ${ }^{2}$

\title{
MATHEMATICAL MODEL OF HEAT PROCESSES IN TERMS OF GAS-SATURATED ROCK BREAKING BY MEANS OF SHEARERS AND TUNNELING MACHINES
}

Purpose. To evaluate the effect of mining and technical factors on friction combustion of methane-air mixtures on the basis of a mathematical model of heat processes while breaking gas-saturated rock mass using shearers and tunneling machines.

Methodology. To achieve the objective, methods of physical and mathematical modeling have been applied to study heat flow in terms of friction interaction of the cutters of a shearer's working organ and to analyze the process of friction spark formation under real conditions of gas-saturated rock mass breaking.

Findings. The research shows that heat flow from the incandescent friction site while rock mass breaking by shearer's working organ is $1.027 \mathrm{~mJ}$; that exceeds the minimal energy of methane-air mixture combustion $(0.28 \mathrm{~mJ})$ by almost 4 times. In terms of critical temperature of methane combustion, that is more than two-fold excess. A process of friction spark formation has been analyzed. It has been defined that only friction sparks of up to $60 \mathrm{mcm}$, which do not have the energy sufficient to inflame the methane-air medium, are not hazardous. The rest of friction particles, struck by the shearer's working organ, are fire- and explosion hazardous within the velocity range of more than $0.5 \mathrm{~m} / \mathrm{s}$.

Originality. Analytic expressions have been obtained to calculate the energy transferred by a friction spark to the dust-methaneair mixture depending on its spark diameter and velocity.

Practical value. Methodology to calculate heat flow in terms of friction interaction has been developed; the methodology helps calculate heat flow from the incandescent friction site under real conditions of gas-saturated rock mass breaking. Methodology to evaluate ignition properties of friction sparks has been elaborated making it possible to calculate values of the parameters of friction sparks and energy transferred by a friction particle to the combustion medium within the period of cooling from the initial temperature down to the temperature of the medium self-ignition. Comparing the obtained values of temperature and energy with the temperature of medium self-ignition and minimal energy of hazardous medium combustion, it is possible to conclude on the spark hazard of the materials and, consequently, to develop preventive measures to limit the use of such materials in real technological processes.

Keywords: rock mass, cutting tool, heat flow, friction spark formation, ignition capability, safety criteria

Introduction. Spark formation in the mine workings of gassy coal mines is rather a widespread phenomenon which can take place in terms of different technological operations. For instance, when mine workings are supported with steel lining and rock pressure is increased, there can be sudden displacements of the lining components accompanied by local deformation of special lining sections with further separation of the metal particles with high temperatures. Radius of particles (sparks) spreading is about $1 \mathrm{~m}$. White color of the sparkles shows that their temperature was more than $1000^{\circ} \mathrm{C}$. According to the results of frame photography, the cooling period of sparks was $0.16-0.3 \mathrm{~s}$. [1]. In terms of $1000{ }^{\circ} \mathrm{C}$ temperature of the ignition source, inductive period of ignition of the methane-air mixture is about $0.15 \mathrm{sec}$ [2]. Considering the fact that the ignition temperature of the methane-air mixture is $650-750^{\circ} \mathrm{C}[2]$, spark formation in terms of sudden displacement of the lining components may be the source of its explosion.

Spark formation is affected considerably by mineralogical composition of the rock. In the process of caving of coal seam roof consisting of the rocks with high content of free silicon dioxide, there arises a danger of methane-air mixture combustion within the worked-out area provoked by fissure formations, dynamic breaking, and friction of the rock components [3].

During rock breaking by the working organs of shearers, a flow of incandescent particles is formed as a result of cutter-

(C) Lebediev Ya. Ya., Stolbchenko O. V., Yurchenko A.A., Luts I. O., Kovbasa V.V., 2020 rock friction; that flow can burn up the surrounding methaneair medium. That source of methane combustion is one of the main causes of explosions occurring within the production and development faces of coal mines.

Friction combustion of the methane-air mixtures (MAM) depends on numerous factors; the basic ones are as follows:

- methane concentration within the zone of rock mass breaking;

- available heat source being sufficient for MAM;

- available means for MAM mitigation;

- available explosive dust.

Due to the fact that the cavity between the working organ and rock mass is quite difficult to be ventilated, that cavity contains the methane-air medium of the explosive concentration [2].

To prevent accidents, it is required to have the data concerning the size of such explosive zones [4]; that will help make measures to exclude potential combustion sources more severe as well as analyze measures for accident prevention.

As a result of the studies carried out [5], it has been determined that the following conditions stipulate formation of the MAM source:

- cutter-rock contact area is characterized by the temperature favoring possible ignition of the combustible mixture;

- period of contact time for the source and the combustible medium necessary for the ignition.

According to studies [5], the specified conditions take place in terms of the formations of so-called "trace" which adjoins the cutter and moves with it during the rock mass break- 
ing. The longer the incandescent trace is, the lower MAMrequired temperature is.

Since maximum temperature of the source cannot exceed maximum temperature of "cutter-rock" friction pair melting and properties of the materials of that pair may be different, then the heat source temperature may differ as well.

Energy characteristics of the cutter trace depend not only upon the physical-chemical properties of the friction pair material but also upon the parameters of rock cutting.

Rocks with high quartz content are the most hazardous in terms of MAM when cutter impacts the rock. Only such rocks as quartz, which have high melting temperature $\left(1227-1727^{\circ} \mathrm{C}\right)$, form incandescent trace. Quartz content in those rocks is more than $50 \%$, and size of quartz grains is more than $70 \mathrm{mcm}$.

Researchers emphasize [5] that in terms of sandstones with the hardness of $f=14-16$ (according to M. M. Protodiakonov's scale), quartz content of 80-90\%, and particle size of 4-8 mcm, combustion of methane-air medium occurs during $1-5 \mathrm{~s}$ from the beginning of rock mass breaking.

In the context of minor rock hardness, when hardness coefficient according to M. M. Protodiakonov is $f<6$, probability of incandescent trace formation is low due to insignificant energy consumption for rock breaking and low cutting power [6].

Researchers [7] come to the conclusion that MAM does not occur until the cutters are sharp. MAM probability increases considerably in case of propagation of wear plane up to the tail made from carbon steel.

Paper [2] studies friction effect on the methane-air mixture combustion during the rock mass breaking. However, that paper does not analyze heat flow from the incandescent site during the rock mass breaking by means of cutters.

Current paper is aimed at developing physical-mathematical model of the process of friction spark formation while breaking gas-saturated rock mass using shearers and tunneling machines as well as the process of losses of heat energy generated as a result of cutter-rock mass friction.

Literature review. According to modern ideas by different researchers concerning the mechanism of rock mass breaking by means of working members of shearers, mechanism of interaction between the working surface of a cutter and surface of the mass being broken within the area of friction contact is as follows [8]: when a cutter effects the rock mass, the rock, being in front of the tool tip, becomes more compact experiencing its further separation with the formation of numerous fine-dispersed particles, dust, and coarse fractions $(>10$ $50 \mathrm{~mm}$ )

Thus, as a result of cutting tool interaction with the rock, rock mass breaking is accompanied by the immediate occurrence and disintegration of the pressure core resulting in the spark formation whose intensity depends upon the properties of rocks, making up the mass under breaking, and technological factors (cutting velocity and motion velocity of the shearer's working organ).

Sparks are the fragments of the incandescent rock grains, which have left the compacted core, and metal particles separated from the cutter. Depending upon the cutting velocity $V_{c}$ and motion velocity $V_{m}$ of the shearer's working organ, sparks temperature is within the range of $500-1400{ }^{\circ} \mathrm{C}$.

Phenomenon of the trace formation from the numerous metal particles left by the cutting edge of a tool, whose temperature is about the temperature of alloy melting (1300$1350{ }^{\circ} \mathrm{C}$ ), may be included in the other heat source in terms of the interaction of the operating surface of a tool and the surface of rock mass under breaking [2].

Based upon experimental data [2], energy balance during rock breaking has been defined. Thus, coal cutting requires the following energy consumption: $50-78 \%$ of energy is consumed for the core formation; $20-46 \%$ is used for cutter-coal friction; $1 \%$ is consumed for the fissure formation.

Consequently, major share of the energy during coal and rock cutting is consumed for the core formation. Coal-cutter friction also uses considerable energy share. In this context, all the energy, used for the rock mass breaking, turns into the heat energy.

It is known that when combustion source affects the combustion mixture, reaction continues without external signs (i.e. without inflammation) for some time. Time period of hidden (without flame) behavior of the combustion reaction is called induction period or combustion delay $\left(\tau_{i n}\right)$ determined in terms of the following dependence [2]

$$
\tau_{\text {in }}=7994 \cdot \exp (-0.0113 \cdot t),
$$

where $t$ is temperature of the combustion source, ${ }^{\circ} \mathrm{C}$.

Temperature of friction surface $t=1200{ }^{\circ} \mathrm{C}$ is preserved for about $13 \mathrm{~ms}$ (Fig. 1) while induction time $\tau_{i n}$, calculated using expression (1), is $10 \mathrm{~ms}$. In terms of temperature $t=1400{ }^{\circ} \mathrm{C}$ preserved for $5 \mathrm{~ms}, \tau_{\text {in }}$ is $1 \mathrm{~ms}$. Combustion of methane-air mixture under such conditions will take place with a high degree of certainty.

Purpose of the paper is to analyze the causes for methaneair mixture combustion under conditions of gas-saturated rock breaking; to study heat flow being the result of the effect of sharers' cutting tools on the rocks; to develop physical-mathematical model of friction spark generation while rock breaking and methodology to calculate inflammatory capacity of the friction sparks.

Results. The paper proposes to divide a process of fractional cutter interaction within the rock mass into three phases (Fig. 2).

During the first interaction phase, cutter impact on the rock is followed by the friction sliding of the cutter; temperature increases within the contact zone up to its maximum (up to the temperature of alloy melting of $1400{ }^{\circ} \mathrm{C}$ ). That phase lasts for about $2 \mathrm{~ms}$. Heat processes of that phase, are connected with heat exchange in terms of dry friction. During that phase, we observe heat generation during friction resulting in the temperature jump within the short period of time.

Further, during the second phase of rock mass breaking, a trace is formed on the face surface; that trace consists of finedispersed incandescent metal fractions. The phase lasts for about $5 \mathrm{~ms}$. During that phase, surface temperature of the friction pairs reaches its maximum value (temperature of cutter alloy melting) and is preserved within the period of contact of the cutter's operating surface and rock mass.

During the third phase, owing to the termination of contact of the cutter's operating surface and rock mass, dimensions of the heated site experience decreasing due to its cooling. Within that phase, the heated surfaces experience their

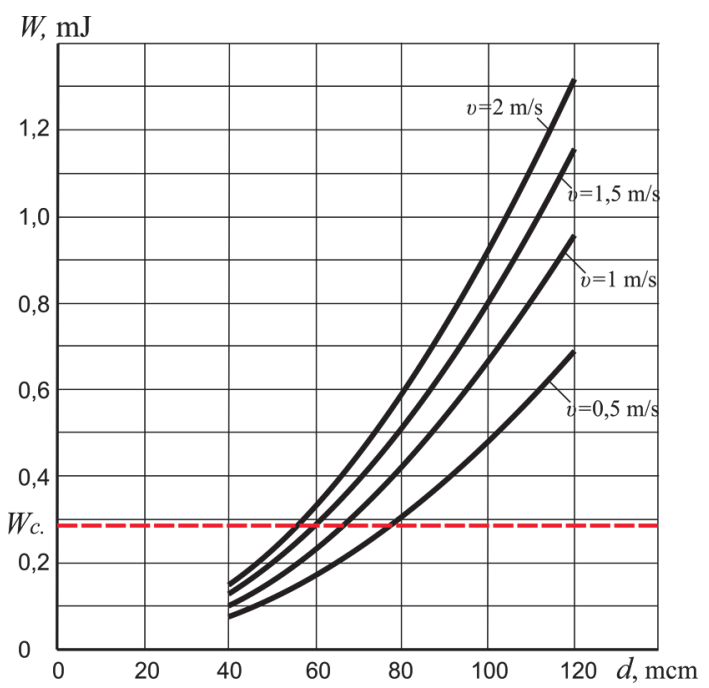

Fig. 1. Dependences of the energy transferred by a friction spark into the dust-methane-air medium upon the spark diameter in terms of different velocities of spark motion 


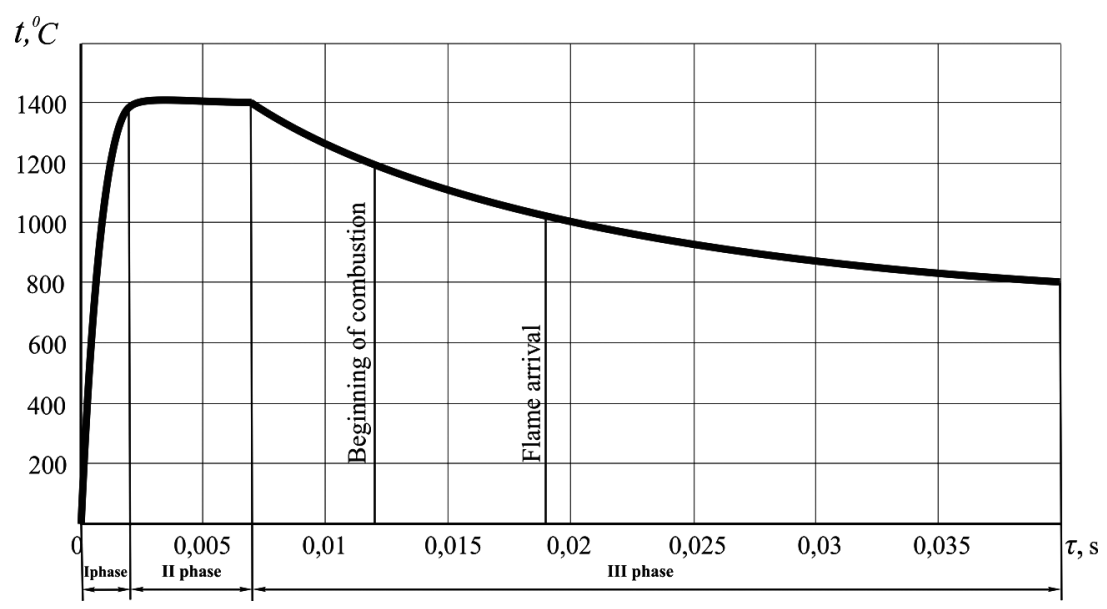

Fig. 2. Heating and cooling dynamics of friction site of the cutter-rock mass interaction

cooling owing to the heat transfer to the surrounding methane-air medium.

Combustion of the methane-air mixture starts at $12 \mathrm{~ms}$; by $19 \mathrm{~ms}$, the flame is already observed. The heated site experiences its cooling from 1400 down to $800{ }^{\circ} \mathrm{C}$ within the period of $40 \mathrm{~ms}$; the most heated area is located at about $30 \mathrm{~mm}$ beyond the cutting edge of the cutter.

While evaluating heat exchange mode in terms of gas-saturated mass by means of a shearer's cutting tool, the calculation is aimed at determining temperature state of the trace surface $t_{t}$ and amount of its exchange heat $Q$ to the methaneair medium per certain period of time $\tau$.

To describe the exchange process between the body surface and the medium, we apply Newton-Richmann law according to which density of heat flow is proportional to the difference in temperatures between the body surface and the environment. Consequently, in terms of the considered heat exchange process from the surface of friction trace, we may write [8]

$$
q_{t}=\alpha\left(t_{t}-t_{\mathrm{mam}}\right),
$$

where $\alpha$ is the coefficient of proportionality (heat exchange), $\mathrm{W} /\left(\mathrm{m}^{2}\right.$ degree $)$ characterizing heat exchange intensity between the body surface and the environment. Numerically, it is equal to the amount of heat exchange unit of the surface per unit of time in terms of temperature difference between the surface and environment being $1{ }^{\circ} \mathrm{C}$; $t_{t}$ is temperature of the trace surface, ${ }^{\circ} \mathrm{C} ; t_{\text {mam }}$ is temperature of ignition of the methane-air medium, ${ }^{\circ} \mathrm{C}$.

Expression (1) makes it possible to determine heat amount $q_{c}$ being removed from the surface unit to the environment per unit of time.

To determine losses of heat energy $Q$ generated as a result of cutter-rock mass friction per time $t_{c}$, basing on (1), we obtain

$$
Q=\alpha\left(t_{i t}-t_{\text {mam }}\right) F \tau_{t},
$$

where $t_{i t}$ is initial trace temperature, ${ }^{\circ} \mathrm{C} ; F$ is trace surface area, $\mathrm{m}^{2}$.

While rock breaking with cutters of the shearers' working organs, cavity between the working organ and rock mass is difficult to be ventilated; thus, heat exchange process takes place within the limited space in terms of natural convection.

In this case, heat exchange should be calculated taking into consideration complex process of heat transfer through the limited space (gap). It is replaces by the equivalent heat conductivity process [9].

$$
q=\frac{\lambda_{e q u}}{\delta}\left(t_{i t}-t_{m a m}\right)
$$

The following concept is introduced $E_{c}=\frac{\lambda_{\text {equ }}}{\lambda_{\text {mam }}}$, where $E_{c}$ is the coefficient of convection. It characterizes the convection effect upon the heat transfer through a gap; $\lambda_{\text {mam }}$ is the heat conductivity coefficient of the methane-air medium, $\mathrm{W} / \mathrm{m} \cdot{ }^{\circ} \mathrm{C} ; \delta$ is gas width, $\mathrm{m} ; \lambda_{\text {equ }}$ is the equivalent coefficient of conductivity, $\mathrm{W} / \mathrm{m} \cdot{ }^{\circ} \mathrm{C}$.

$$
\lambda_{\text {equ }}=E_{c} \cdot \lambda_{\text {mam }} .
$$

The coefficient of convection depends on number $(\mathrm{Gr} \cdot \mathrm{Pr})$, i.e.

$$
E_{c}=f(G r \cdot \operatorname{Pr}),
$$

where $G r$ is Grashof number determining intensity of free motion of methane-air medium [8]

$$
G r=\frac{g F^{3} \beta\left(t_{i t}-t_{m a m}\right)}{v^{2}},
$$

where $g$ is free fall acceleration, $\mathrm{m} / \mathrm{s}^{2} ; b$ is the temperature coefficient of volumetric heat carrier expansion for gases in terms of not very high constant pressure, $\beta=\frac{1}{273+t_{0}} \mathrm{~K}^{-1}$.

Prandtl number Pr determines the effect of thermophysical properties of the environment on the process [8].

$$
\operatorname{Pr}=\frac{v \rho C_{p}}{\lambda}
$$

where $n$ is kinematic viscosity, $\mathrm{m}^{2} / \mathrm{s} ; \rho$ is density of methaneair medium, $\mathrm{kg} / \mathrm{m}^{3} ; C_{p}$ is specific heat capacity of the medium in terms of constant pressure, $\mathrm{kJ} /\left(\mathrm{kg} \cdot{ }^{\circ} \mathrm{C}\right)$.

1. If number $(\mathrm{Gr} \cdot \mathrm{Pr})<10^{3}$, then $E_{c}=1 ; \lambda_{\text {equ }}=\lambda_{\text {l }}$.

Heat transfer occurs only by means of heat conductivity.

2. If $10^{3}<(G r \cdot \operatorname{Pr})<10^{6}$, then $E_{c}=0.105(G r \cdot \operatorname{Pr})^{0.3}$.

3. If $10^{6}<(G r \cdot \operatorname{Pr})<10^{10}$, then $E_{c}=0.4(G r \cdot \operatorname{Pr})^{0.2}$.

Paper [10] proposes formula to calculate $E_{c}$ for the whole area of complex $(\mathrm{Gr} \cdot \mathrm{Pr})>10^{3}$

$$
E_{c}=0.18(G r \cdot \operatorname{Pr})^{0.25} \text {. }
$$

Taking into consideration (3-7), expression (2) may be represented as follows

$$
\begin{gathered}
Q=0.18(G r \cdot \operatorname{Pr})^{0.25} \frac{\lambda_{\text {mam }}}{\delta}\left(t_{i t}-t_{\text {mam }}\right) F \tau_{t} \\
\beta=\frac{1}{273+t_{\text {mam }}} .
\end{gathered}
$$

Taking into account (8-9), we obtain

$Q=0.18\left[\frac{9.81 \cdot F^{3}\left(t_{i t}-t_{\text {mam }}\right)}{v\left(273+t_{\text {mam }}\right)} \frac{\rho C_{p}}{\lambda_{\text {mam }}}\right]^{0.25} \frac{\lambda_{\text {mam }}}{\delta}\left(t_{i t}-t_{\text {mam }}\right) F \tau_{t}$. 
Average trace temperature $t_{i t}$ in equation (10) is $\frac{t_{i t}+t_{\text {mam }}}{2}$, consequently, taking that into consideration, we obtain

$$
Q=0.14\left(\frac{\rho_{\text {mam }} C_{p}}{v_{\text {mam }}}\right)^{0.25} \frac{F_{t}^{1.75} \lambda_{\text {mam }}^{0.75}}{\delta} \frac{\left(t_{i t}-t_{\text {mam }}\right)^{1.25}}{\left(273+t_{\text {mam }}\right)^{0.25}} \tau_{t} .
$$

Calculation results according to expression (10), in terms of values of the parameters for real conditions, show that the heat amount within the friction site exceeds the heat amount required to inflame methane-air medium almost by 4 times, and excess of critical methane-inflammation temperature is higher by more than 2 times.

That makes it possible to conclude that in terms of friction cutter-rock mass interaction, heat factor has effect upon the hazard of methane inflammation within the near-face zone.

Combustion capacity of the friction spark was evaluated based on the following assumptions.

Sparks of impact or friction may be the combustion source for gas-air combustion mixture under the following conditions [9]:

- the temperature of incandescent particles is higher than the temperature of self-combustion of the inflammable mixture contacting it;

- heat amount given by the spark during its cooling is enough to heat the environment up to the inflammation temperature;

- the period of combustion source action (spark) is not less than the period of the induction of combustible mixture.

During cooling, despite the high temperature, spark may give comparatively minor heat amount since its mass is very small. Moreover, after cooling lower than the temperature of self-ignition of the combustion mixture, the spark is not hazardous - it cannot inflame the mixture anymore.

In its essence, the forced inflammation of the combustion mixture from the spark is similar to the process of heat selfignition [5]. During its motion, a spark heats up its surrounding volume of the combustible mixture. In this context, during the motion, there occurs exothermal reaction of the spark oxidation in the air accompanied by the intensifying fluorescence of the friction sparks and increasing amount of heat required to form the heating zone within the combustion temperature capable of inducing chemical reaction of combustion.

Within the trajectory of the moving spark, the heated volume is approximately cylindrical in the shape. Part of a cylinder of the length equal to critical diameter can be taken as the critical volume.

If we assume that combustion mixture gets the energy transferred by a solid body as a result of the convection process, then uniform temperature change is possible under condition of far lower resistance of heat conductivity comparing to the convection resistance on the body surface. The thermal balance of the system resistances is characterized by the criterion of stationary heat exchange between the heated solid body and the environment $B i[10]$

$$
B i=\frac{\alpha d_{p}}{\lambda_{p}},
$$

where $\alpha=\frac{N u \lambda_{\text {mam }}}{d_{p}}$ is the coefficient of heat transfer, $\mathrm{W} /\left(\mathrm{m}^{2} \cdot{ }^{\circ} \mathrm{C}\right)$.

In this context, $N u=0.662 \cdot \operatorname{Pr}^{0.33} \operatorname{Re}^{0.5}$ is heat Nusselt criterion, where $\operatorname{Pr}=\frac{v_{\text {mam }}}{\chi}$ is heat Prandtl number; $\operatorname{Re}=\frac{v_{p} d_{p}}{v_{\text {mam }}}$ is the Reynolds number; $\chi=\frac{\lambda_{\text {mam }}}{\rho_{\text {mam }} c_{p}}$ is the coefficient of temperature conductivity of the methane-air mixture; $v_{\text {mam }}$ is ki- nematic viscosity of the methane-air mixture, $\mathrm{m}^{2} / \mathrm{s} ; d_{p}$ is diameter of a friction particle, $\mathrm{m} ; \lambda_{p}$ is coefficient of heat conductivity of a friction particle, $\mathrm{W} / \mathrm{m} \times \mathrm{K}$.

According to GOST 12.1.004-91, heat transfer coefficient $\alpha$ may be determined using formula

$$
\alpha=188 \sqrt{\mathrm{v}_{p}},
$$

where $v_{p}$ is velocity of the motion of a heated friction particle, $\mathrm{m} / \mathrm{s}$.

Results of calculations performed according to expression (12) show that in terms of friction pair, under conditions of rock breaking by the shearer's operating organ, the value of number $\mathrm{Bi}$ is within the range from 0.001 to 0.004 , i. e. internal thermal resistance of the system is far lower than the external convective thermal resistance.

In the context of minimal Biot numbers, when $\mathrm{Bi} \rightarrow 0$, cooling process of incandescent particle with radius $R$ may be expressed as follows [8]

$$
\Theta_{p}=1-\frac{R(\sin \sqrt{3 B i}) \frac{r}{R}}{r \sqrt{3 B i}} e^{-3 B i F o},
$$

where $\Theta_{p}$ is relative excessive temperature, $\mathrm{K} ; r$ is current radius, $\mathrm{m}$.

Formula (14) helps define Fourier criterion in terms of relative excessive temperature of the spherical surface in the form of

$$
F o=-\frac{1}{3 B i} \ln \left[\frac{\sqrt{3 B i}\left(1-\Theta_{p}\right)}{\sin \sqrt{3 B i}}\right] .
$$

Fire hazard of the friction sparks is determined by the amount of heat generated in them; it depends on: initial conditions (pair temperature and environment), mode of friction contact, geometry of the friction pair, thermophysical properties of the materials of the friction pair, and the environment. Based on the consideration of the mentioned parameters, methodology to evaluate ignition capability of friction sparks is proposed.

Cooling period of the incandescent friction particles may be defined using expression [4]

$$
\tau=\frac{F o}{\lambda_{p}} d_{p}^{2} c_{p} \rho_{p},
$$

where $c_{p}$ is heat capacity of the incandescent particle.

Energy transferred by the particle to the combustion substance during its cooling period may be define with the help of formula [9]

$$
W(\tau)=\left[\alpha S_{p}\left(t_{p}-t_{\text {mam }}\right)\right]\left(1-e^{-B i F o}\right) \frac{1}{B i F o},
$$

where $S_{u}$ is an area of the heated particle surface, $\mathrm{m}^{2} ; S_{p}=\pi \mathrm{d}^{2}$. Average temperature of the particle in equation (15) is $\frac{t_{p}+t_{\text {mam }}}{2}$, hence

$$
W(\tau)=\left[\alpha S_{p}\left(\frac{t_{p}+t_{\text {mam }}}{2}-t_{\text {mam }}\right)\right]\left(1-e^{-B i F o}\right) \frac{1}{B i F o},
$$

or

$$
W(\tau)=\left[\alpha S_{p}\left(\frac{t_{p}-t_{\text {mam }}}{2}\right)\right]\left(1-e^{-B i F o}\right) \frac{1}{B i F o} .
$$

Taking into consideration (12, 13 and 15), expression (17) may be represented as follows 


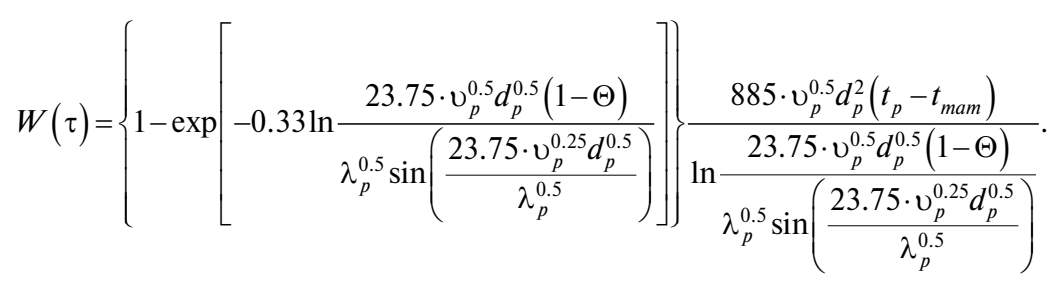

Expression (18) takes into account parameters of methane-air medium and physical properties of the friction pairs while rock mass breaking; that helps determine the temperature of friction particles depending on its velocity and geometrical parameters rather adequately for engineering calculation.

Basing on the comparison of the obtained results with the minimal energy required for methane-air mixture combustion (equal only to a share of millijoule while the energy of direct initiation of the detonation is roughly equivalent to $17 \mathrm{~kg}$ of trinitrotoluene), it is possible both to evaluate the safety degree in the process of gas-saturated mass breaking by the sharer's cutting organ and develop measures to prevent accidents under real technological processes.
In the initial stage, only combustion of methane-air mixture is implemented; first, flame propagates from the point in the laminar burning mode with the velocity of about $0.3 \mathrm{~m} / \mathrm{s}$ [11]. To study the process of spark formation using physicalmathematical model (18) and to determine the effect of spark motion velocity $\left(v_{p}\right)$ and their values $\left(d_{p}\right)$ on the value of energy required for combustion medium ignition, transform mathematical model (19) into the dependence expressing the effect of dimension of particles $d_{p}$ upon the value transferred further by a friction particle into the methane-air medium $(W)$ from $v_{p}$. To do that, we introduce values of parameters $\lambda_{p}, t_{p}$; $\Theta$, and $t_{\text {mam }}: t_{\text {mam }}=1273 \mathrm{~K}$ into expression (18) taking into account induction properties of methane; $t_{p}=1673 \mathrm{~K} ; \Theta=0$,2; $\lambda_{p}=42 \mathrm{~W} / \mathrm{m} \times \mathrm{K}$. As a result, we obtain

$$
W(\tau)=\left\{1-\exp \left[-0.33 \ln \frac{2.94 \cdot v_{p}^{0.5} d_{p}^{0.5}}{\sin \left(3.67 \cdot v_{p}^{0.25} d_{p}^{0.5}\right)}\right]\right\} \frac{354 \cdot 10^{3} \cdot v_{p}^{0.5} d_{p}^{2}}{\ln \frac{2.94 \cdot v_{p}^{0.5} d_{p}^{0.5}}{\sin \left(3.67 \cdot v_{p}^{0.25} d_{p}^{0.5}\right)}} .
$$

Initial velocity of friction particles $v_{0 p}$ at the moment of their formation is equal to the rotational velocity of the shearer's working organ, i. e. to cutting velocity $u_{p}$ being determined using formula

$$
\mathrm{v}_{0 p}=\mathrm{v}_{p}=\frac{\pi D_{d . s .} n_{\text {rot. }}}{60},
$$

where $D_{\text {d.s. }}$ is the diameter of the shearer's working organ, m; $n_{\text {rot. }}$ is frequency of the working organ rotation, rot $/ \mathrm{min}$.

During the motion time of friction particles, their velocity decreases down to its fall owing to the air resistance. That is why, average velocity may be taken as equal to $0.6 v_{0 p}$.

Cutting velocity of the shearers' working organs applied nowadays is within the range of $1.0-5.0 \mathrm{~m} / \mathrm{s}$; thus, average velocity of friction particles is $0.6-3 \mathrm{~m} / \mathrm{s}$.

Relative excessive temperature ?p is determined according to the formula represented in GOST 12.1.004-91

$$
\Theta_{p}=\frac{t_{p}-t_{\text {mam }}}{t_{p}-t_{\operatorname{mam} 0}}
$$

where $t_{\text {mam } 0}$ is initial temperature of the methane-air medium, ${ }^{\circ} \mathrm{C}$.

Based on the calculations performed in terms of the obtained expression (20), Figs. 1, 3 demonstrate dependences of the energy transferred by the friction spark into the dust-meth-

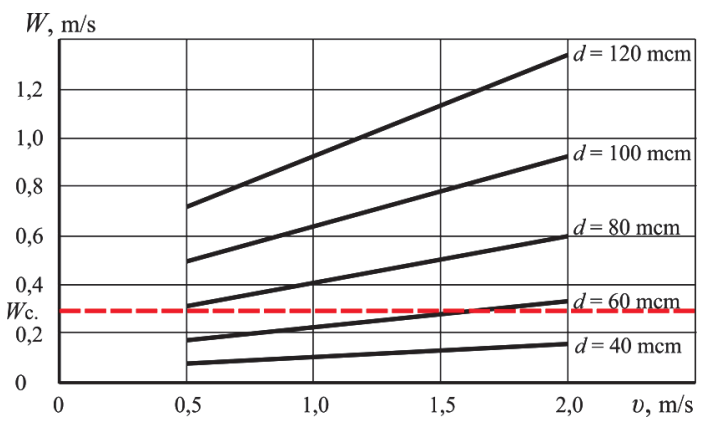

Fig. 3. Dependences of energy transferred by s spark into the dust-methane-gas mixture upon the velocity of spark motion in terms of different spark diameters ane-air mixture upon the spark diameter and spark velocity within the analyzed range.

The represented graph (Fig. 3) shows that along with the increasing spark velocity, its transferred energy grows monotonously irrespective of the values of spark diameter within the analyzed diameter. In this context, only friction sparks of up to $60 \mathrm{mcm}$, which do not have the energy sufficient to inflame the methane-air medium, are considered to be not hazardous. The rest of friction particles, struck by the shearer's working organ, are fire- and explosion hazardous within the velocity range of more than $0.5 \mathrm{~m} / \mathrm{s}$ irrespective of their motion velocity.

The performed calculations show that the single friction spark may inflame the methane-air mixture only under conditions of sufficient amount of heat energy which that spark has and which depends upon the dimension of friction sparks, its motion velocity within the dust-methane-air medium, and physical-chemical properties of the particles.

Besides, methane inflames with some delay called the period of induction, i.e. apart from the specified heat amount, inflammation of methane-air mixture required maintenance of that heat during the period of induction.

If there are favorable conditions for the formation of cloud of fine-dispersed metal and rock particles heated up to high incandescent temperature, then the ignition of combustion methane-air mixture with normal oxygen content is real irrespective of their diameter.

\section{Conclusions.}

1. In terms of friction cutter interaction with gas-saturated rock, heat factor has dominating effect upon the hazard of methane combustion within the near-face area.

2. Methodology to calculate heat flow in terms of interaction between the shearer's operating organ and rock mass has been developed; the methodology helps calculate heat flow from the incandescent trace formed by the cutting edge while gas-saturated rock breaking. Heat amount generated owing to the friction is $1.027 \mathrm{~mJ}$ being higher than the minimal energy, required to inflame combustion medium, by 4 times. Ignition process of combustion methane medium starts at $12 \mathrm{~ms}$; by 19 $\mathrm{ms}$, the flame is already observed. The heated site from 1400 down to $8000 \mathrm{C}$ experiences its cooling within $40 \mathrm{~ms}$; the most heated area is located at about $30 \mathrm{~mm}$ beyond the cutting edge of a tool. 
3. Mathematical model of spark formation in terms of friction during gas-saturated rock mass breaking has been developed. The following conditions affect the capacity of friction sparks to inflame the surrounding methane-air medium: initial conditions, mode of friction contact, geometrical parameters of the friction pair as well as thermophysical properties of friction pairs and combustion medium.

4. Methodology to identify ignition properties of the incandescent particles has been elaborated making it possible to calculate values of energy parameters of the heat transfer process when rock mass is broken by shearers.

5. Analytical expressions have been obtained to calculate energy parameters of the shearers' cutters interaction with the rock mass under conditions of gas-saturated coal mass breaking. It has been specified that only friction sparks of up to $60 \mathrm{mcm}$, which do not have the energy sufficient to inflame the methaneair medium, are not hazardous. The rest of friction particles, struck by the shearer's working organ, are fire- and explosion hazardous within the velocity range of more than $0.5 \mathrm{~m} / \mathrm{s}$.

\section{References.}

1. Khalimendik, Yu. M., Baryshnikov, A.S., \& Khalimendik, V. Yu. (2016). Safe use of lock joints of arc flexible support. Geotechnical mechanics, (128), 61-69.

2. Golinko, V. I., Yavorskii, A. V., Lebedev, Ya. Ya., \& Yavorskaia, Ye. A. (2014). Effect of the parameters of gas-saturated breaking upon its heat exchange with the methane-air. Geotechnical mechanics, (117), 161-175.

3. Botvenko, D. V., Kazantsev, V. G., Sazonov, M.S., \& Vysotskii, V.V. (2014). On possibility of methane-air mixture inflammation from piezoelectric rock effect. Fire and industrial safety, (1), 96-98.

4. Struchalin, V. G., Ponomariov, V. M., \& Navtsenia, V. Yu. (2014). Possible accidents while filling rail tank cars with highly flammable liquids. Science and technology of transport, 4(44), 85-90.

5. Merzliakov, V. G., \& Dereviashkin, I. V. (2015). Developing measures to prevent methane and coal dust combustion during operation of shearers and tunneling machines. Fire and explosion safety, 24(4), 39-46.

6. Kolesnichenko, I. Ye., Artemiev, V. B., Kolesnichenko, Ye. A., Cherechukin, V. G., \& Liubomichenko, Ye. I. (2016). Theory of combustion and explosion of methane and coal dust. Coal, (6), 30-35. https://doi.org/10.18796/0041-5790-2016-6-30-35.

7. Prokopenko, S.A., \& Ludzish, V.S. (2015). Evolution of cutter structures for shearers. Mining industry, 2(120), 65-66.

8. Gorev, V. A., \& Fomina, M. V. (2016). Simplified calculation of heat exchange on plane surfaces. Fire and explosion safety, 25(3), 5-14. https://doi.org/10.18322/PVB.2016.25.03.5-14 9. Yemelianov, R.T., Turysheva, Ye.S., Pylaiev, M.A., \& Khodzhaieva, M. M. (2015). Studying a process of heat transfer within the limited space. Vestnik of KrasSAU, (6), 73-78.

10. Kudinov, V.A., Kudinov, I. V., \& Skvortsova, M. P. (2015). Generalized functions and additional boundary conditions in the problems of heat conductivity for multilayered bodies. Journal of computational mathematics and mathematical physics, 55(4), 669-680.

11. Vasiliev, A. A., Pinaiev, A. V., Trotsiuk, A. V., Fomin, P.A., Trubitsyn, A. A., \& Trubitsyna, D. A. (2015). Complete suppressing of detonation and combustion of methane mixtures by means of dust haze. Fire and industrial safety, (4), 12-21.

\section{Математична модель теплових процесів при руйнуванні газонасиченого гірського масиву очисними та прохідницькими комбайнами}

\author{
Я. Я. Лєбєдев ${ }^{1}$, О. В. Столбченко ${ }^{1}$, А. А. Юрченко ${ }^{1}$, \\ I. О. Лутс ${ }^{1}$, В. В. Ковбаса ${ }^{2}$
}

1 - Національний технічний університет «Дніпровська політехніка», м. Дніпро, Україна, e-mail: elena_aot@ukr.net 2 - «ШУ Першотравенське», ЧАО «ДТЕК Павлоградвугілля», м. Першотравенськ, Україна

Мета. Оцінка впливу гірничотехнічних факторів на фрикційне займання метаноповітряної суміші на підставі математичної моделі теплових процесів при руйнуванні газонасиченого гірського масиву очисними та прохідницькими комбайнами.

Методика. Для досягнення поставленої мети використані методи фізичного й математичного моделювання, дослідження теплового потоку при фрикційній взаємодії різців виконавчого органу комбайна, а також процесу фрикційного іскроутворення за реальних умов руйнування газонасиченого гірського масиву.

Результати. Проведені дослідження свідчать про те, що тепловий потік від розпеченого фрикційного майданчика при руйнуванні гірського масиву виконавчим органом комбайна становить 1,027 мДж, перевищує мінімальну енергію займання метаноповітряної суміші (0,28 мДж) майже в 4 рази, а при перевищенні критичної температури займання метану - більш ніж у 2 рази. Досліджено процес утворення фрикційних іскор. Встановлено, що безпечними є лише іскри розміром до 60 мкм, що не мають енергії, достатньої для підпалювання метаноповітряного середовища. Решта фрикційних часток, кресані виконавчим органом комбайна, є пожежовибухонебезпечними в діапазоні швидкостей більше 0,5 м/с.

Наукова новизна. Отримані аналітичні вирази для розрахунку енергії, що віддається фрикційною іскрою в пилогазоповітряну суміш, у залежності від діаметра іскри та її швидкості.

Практична значимість. Розроблена методика розрахунку теплового потоку при фрикційній взаємодії, що дозволила розрахувати тепловий потік від розпеченого фрикційного майданчика за реальних умов руйнування газонасиченого гірського масиву. Розроблена методика оцінки запалювальної властивості фрикційних іскор, шо дозволила розрахувати значення параметрів фрикційних іскор і енергії, що віддається фрикційною часткою займистого середовища за час охолодження від початкової температури до температури самозаймання середовища. Порівнюючи отримані значення температури та енергії з температурою самозаймання середовища й мінімальною енергією запалювання небезпечного середовища, можна зробити висновок про іскронебезпечність матеріалу i, отже, розробити профілактичні заходи щодо обмеження використання цих матеріалів у реальних технологічних процесах.

Ключові слова: гірський масив, ріжучий інструмент, тепловий потік, фрикційне іскроутворення, запалювальна властивість, здатність, критерії безпеки

\section{Математическая модель тепловых}

\section{процессов при разрушении газонасыщенного горного массива очистными и проходческими комбайнами}

\section{Я. Я. Лебедев ${ }^{1}$, Е. В. Столбиенко ${ }^{1}$, А.А. Юрченко ${ }^{1}$, И. О. Лутс ${ }^{1}$, В. В. Ковбаса}

1 - Национальный технический университет «Днепровская политехника», г. Днепр, Украина, e-mail: elena_aot@ ukr.net

2 - «ШУ Першотравенское», ЧАО «ДТЭК Павлоградуголь», г. Першотравенск, Украина

Цель. Оценка влияния горнотехнических факторов на фрикционное воспламенение метановоздушных сме- 
сей на основании математической модели тепловых процессов при разрушении газонасыщенного горного массива очистными и проходческими комбайнами.

Методика. Для достижения поставленной цели использованы методы физического и математического моделирования, исследования теплового потока при фрикционном взаимодействии резцов исполнительного органа комбайна, а также процесса фрикционного искрообразования при реальных условиях разрушения газонасыщенного горного массива.

Результаты. Проведенные исследования свидетельствуют о том, что тепловой поток от раскаленной фрикционной площадки при разрушении горного массива исполнительным органом комбайна составляет 1,027 мДж, превышает минимальную энергию воспламенения метановоздушной смеси (0,28 мДж) почти в 4 раза, а при превышении критической температуры воспламенения метана - более чем в 2 раза. Исследован процесс образования фрикционных искр. Установлено, что безопасными являются только искры размером до 60 мкм, которые не обладают энергией, достаточной для поджигания метановоздушной среды. Остальные фрикционные частицы, высекаемые исполнительным органом комбайна, являются пожаровзрывоопасными в диапазоне скоростей более $0,5 \mathrm{~m} / \mathrm{c}$.

Научная новизна. Получены аналитические выражения для расчёта энергии, отдаваемой фрикционной ис- крой в пылегазовоздушную смесь, в зависимости от диаметра искры и её скорости.

Практическая значимость. Разработана методика расчёта теплового потока при фрикционном взаимодействии, которая позволила рассчитать тепловой поток от раскалённой фрикционной площадки при реальных условиях разрушения газонасышенного горного массива. Разработана методика оценки поджигательной способности фрикционных искр, которая позволила рассчитать значения параметров фрикционных искр и энергии, отдаваемой фрикционной частицей горючей среде за время остывания от начальной температуры до температуры самовоспламенения среды. Сравнивая полученные значения температуры и энергии с температурой самовоспламенения среды и минимальной энергией зажигания опасной среды, можно сделать вывод об искроопасности материала и, следовательно, разработать профилактические меры по ограничению использования этих материалов в реальных технологических процессах.

Ключевые слова: горный массив, режущий инструмент, тепловой поток, фрикционное искрообразование, поджигательная способность, критерии безопасности

Recommended for publication by S. I. Cheberiachko, Doctor of Technical Sciences. The manuscript was submitted 29.03.19. 